\title{
Pengaruh Penerapan Strategi Pelaksanaan Perilaku Kekerasan terhadap Tanda Gejala Klien Skizofrenia di Rumah Sakit Jiwa Daerah Provinsi Jambi
}

\author{
Siti Makhruzah ${ }^{1}$, Vevi Suryenti Putri ${ }^{2}$, Rahmi Dwi Yanti ${ }^{3}$ \\ ${ }^{1-3}$ Program Studi S1 Keperawatan STIKBA \\ Email : bundavierza@gmail.com
}

Submitted : 23/07/2020

Accepted: 12/02/2021

Published: $06 / 03 / 2021$

\begin{abstract}
The prevalence of violent behavior committed by people with schizophrenia is $19.1 \%$. One of the nurse's independent actions is the provision of implementation Strategy on the client's violent behavior. The study aimed to determine the influence of applying the strategy of implementing violence behavior toward signs symptoms of schizofrenia clients at psychiatric hospital Jambi province. This study was conducted from 01st to 22nd January 2020. It used preexperimental with one group pre and post test design. The populations were all of schizophrenic clients with violent behavior who were hospitalized with sample as many as 30 people. The collecting of data was conducted by using purposive sampling technique. The findings were obtained that mean value of signs symptom pre-test 17.0 and after the implementing of SP is determined to occur a decrease in the mean value of post-test symptoms of 7.93. Bivariate analysis with the t test obtained $p$ value of $0,000(<0.05)$ so that there is an influence of the implementation of the PK implementation strategy on the decrease in symptoms
\end{abstract}

Keywords: implementation strategy, symptoms, violent behavior

\begin{abstract}
Abstrak
Prevalensi perilaku kekerasan yang dilakukan oleh orang dengan skizofrenia adalah $19,1 \%$. Salah satu tindakan mandiri perawat adalah pemberian Strategi Pelaksanaan pada klien perilaku kekerasan. Tujuan penelitian ini adalah untuk melihat apakah ada pengaruh penerapan strategi pelaksanaan perilaku kekerasan terhadap tanda gejala klien skizofrenia di RSJD Provinsi Jambi. Penelitian dilakukan pada 01 sampai dengan 22 Januari 2020. Desain penelitian yang digunakan adalah pre-experimental dengan one group pre dan post test design. Populasi dalam penelitian ini adalah seluruh klien skizofrenia dengan perilaku kekerasan yang dirawat inap dengan jumlah sampel 30 orang. Pengumpulan data dilakukan dengan teknik purposive sampling. Hasil penelitian didapatkan nilai mean tanda gejala pre test 17,0 dan setelah penerapan SP diketahui terjadi penurunan nilai mean tanda gejala post test 7,93. Analisa bivariat dengan uji t test didapatkan nilai $\mathrm{p}$ value $0,000(<0,05)$ sehingga ada pengaruh penerapan strategi pelaksanaan PK terhadap penurunan tanda gejala.
\end{abstract}

.Kata Kunci : perilaku kekerasan, strategi pelaksanaan, tanda gejala,

\section{PENDAHULUAN}

Skizofrenia adalah sekumpulan sindroma klinik yang ditandai dengan perubahan kognitif, emosi, persepsi dan aspek lain dari perilaku. Skizofrenia merupakan suatu kondisi gangguan psikotik yang ditandai dengan gangguan utama dalam pikiran, emosi dan perilaku yang terganggu, dimana berbagai pemikiran tidak saling berhubungan secara logis, persepsi dan perhatian yang keliru, afek yang datar atau tidak sesuai dengan berbagai gangguan aktivitas motorik yang bizarre disebut skizofrenia(Kunter,2009).

Menurut data World Health Organitation (WHO), terdapat sekitar 35 juta orang terkena depresi, 60 juta orang terkena bipolar, 21 juta terkena skizofrenia, serta 47,5 juta terkena demensia. Riskesdas 2013 proporsi gangguan jiwa 1,7\% (permil) 
sedangkan Riskesdas 2018 prevalensi Rumah Tangga dengan ART gangguan jiwa skizofrenia/psikosis meningkat drastis menjadi $6,7 \%$ dengan prevalensi provinsi tertinggi adalah Bali $11 \%$. Untuk prevalensi Rumah Tangga dengan ART gangguan jiwa skizofrenia/psikosis di provinsi Jambi mencapai $7 \%$ pada Riskesdas 2018 (Kemenkes 2018).

Gangguan jiwa adalah kesulitan yang harus dihadapi oleh seseorang karena hubungannya dengan orang lain, kesulitan karena persepsinya tentang kehidupan dan sikapnya terhadap dirinya sendiri. Gangguan jiwa yang disebut juga dengan gangguan mental merupakan gangguan dalam cara berpikir (cognitive), kemauan (volition), emosi (affective), tindakan (psychomotor), salah satu gangguan jiwa yang sangat mempengaruhi dan mengganggu kehidupan individu adalah skizofrenia ( Yosef, 2010).

Pada penderita skizofrenia terdapat 2 gejala secara umum, yaitu berupa gejala positif dan gejala negatif. Gejala positif pada penderita skizofrenia antara lain timbulnya delusi/waham, halusinasi, gaduh gelisah, agresif, kekacauan alam pikiran. Gejala negatif meliputi sulit memulai pembicaraan, afek tumpul atau datar, berkurangnya motivasi, berkurangnya atensi, pasif, apatis dan penarikan diri secara sosial dan rasa tidak nyaman. ${ }^{6}$ Salah satu gejala positif dari skizofrenia yang sering muncul adalah perilaku kekerasan. ${ }^{7}$ Prevalensi perilaku kekerasan yang dilakukan oleh orang dengan skizofrenia adalah $19,1 \% .^{6}$

Perilaku kekerasan merupakan salah satu respon terhadap stressor yang dihadapi seseorang. Respon ini dapat menimbulkan kerugian baik kepada diri sendiri, orang lain, maupun lingkungan. Melihat dampak dan kerugian yang ditimbulkan maka penanganan klien dengan perilaku kekerasan perlu dilakukan oleh tenaga profesional. Perawat sebagai tenaga profesional turut memiliki tanggung jawab untuk memberikan pelayanan keperawatan sesuai kompetensi dan kewenangan yang dimiliki secara mandiri maupun bekerjasama dengan anggota kesehatan lainnya, dalam bentuk asuhan keperawatan (Keliat, 2013).

Pemberian asuhan keperawatan merupakan proses terapeutik yang melibatkan hubungan kerjasama antara perawat dengan klien, keluarga atau masyarakat untuk mencapai tingkat kesehatan yang optimal.Tindakan keperawatan yang dilakukan kepada klien berupa tindakan keperawatan generalis (Keliat, 2013).

Data diagnosa keperawatan pasien yang berada diruang rawat inap Rumah Sakit Jiwa Provinsi Jambidari bulan Januari hingga Juli 2019 tercatat sebanyak 80 klien dengan diagnosa keperawatan resiko perilaku kekerasan, untuk lebih rinci dapat dilihat pada tabel berikut ini :

Tabel 1. Diagnosa Keperawatan pasien Rawat Inap di Rumah Sakit Jiwa Provinsi Jambi pada Januari s.d Juli 2019

\begin{tabular}{clcll}
\hline No & Ruangan & Halusinasi & PK & DPD \\
\hline 1 & Epsilon & 189 & 9 & 2 \\
2 & Srikandi & 41 & 17 & 0 \\
3 & Arimbi & 280 & 0 & 0 \\
4 & Beta & 194 & 0 & 0 \\
5 & Arjuna & 185 & 4 & 13 \\
6 & Yudistira & 220 & 0 & 0 \\
7 & Gama & 88 & 3 & 0 \\
8 & Alfha & 941 & 26 & 1 \\
9 & Shinta & 96 & 6 & 56 \\
10 & Delta & 192 & 0 & 0 \\
11 & Omega & 131 & 3 & 7 \\
12 & Teta & 593 & 1 & 0 \\
13 & Sigma & 250 & 3 & 1 \\
14 & Pega & 56 & 8 & 49 \\
15 & Zetta & 35 & 0 & 4 \\
\hline & Jumlah & 3.491 & 80 & 133 \\
\hline
\end{tabular}

Data Primer, 2020

Tindakan keperawatan generalis pada klien perilaku kekerasan dilakukan dalam 4 macam strategi pelaksanaan (SP) 
yaitu: mengontrol perilaku kekerasan dengan cara fisik yaitu tarik nafas dalam dan pukul kasur bantal, mengontrol perilaku kekerasan dengan cara minum obat secara teratur, mengontrol perilaku kekerasan dengan cara verbal yaitu: menceritakan perilaku kekerasan, bicara baik (meminta, menolak dan mengungkapkan perasaan), mengontrol perilaku kekerasan dengan cara spritual, pada setiap pertemuan klien memasukkan kegiatan yang telah dilatih untuk mengatasi masalah kedalam jadwal kegaiatan harian ( Direja,2011). Standar pelaksanaan komunikasi (SP) dengan klien resiko perilaku kekerasan menjabarkan bahwa teknik mengatasi marah terbagi menjadi : latihan relaksasi nafas dalam, pukul bantal kasur, olahraga, gerakan fisik, latihan deenskalasi (curhat), latihan bicara yang baik, latihan spiritual, dan latihan minum obat yang benar (Keliat, 2013).

Berdasarkan survey awal yang dilakukan peneliti pada tanggal 05 Oktober 2019 di Instalasi Gawat Darurat (IGD) Rumah Sakit Jiwa Daerah Provinsi Jambi didapatkan bahwa alasan utama keluarga dan penanggung jawab membawa klien untuk dirawat inap adalah karena mengamuk dan tidak bisa dikendalikan lagi oleh anggota keluarga maupun lingkungan sekitar. Hasil observasi peneliti terhadap 2 orang klien yang dirawat di ruang Alpha dengan diagnosa keperawatan perilaku kekerasan sebelum mendapatkan asuhan keperawatan perilaku kekerasan, klien belum bisa melakukan pengontrolan marah, klien tampak berkata kasar, memaki, mengancam dan mencoba melukai orang lain. Peneliti juga mendapatkan informasi bahwa klien tidak pernah mendapatkan perlakuan atau latihan tentang strategi pelaksanaan perilaku kekerasan selama dirawat diRumah Sakit Jiwa Daerah Provinsi Jambi.

Hasil wawancara dengan perawat pelaksana di Ruang Alpha ditemukan masalah bahwa penerapan strategi pelaksanaan perilaku kekerasan belum bisa berjalan optimal, hal ini disebabkan karena pemberian strategi pelaksanaan perilaku kekerasan tidak dilaksanakan secara terus menerus tetapi hanya pada saat klien melakukan perilaku kekerasan, dan strategi pelaksanaan yang dilakukan pada klien langsung pada fase kerja. Perawat juga menjelaskan bahwa biasanya klien dengan perilaku kekerasan yang masih sangat menonjol gejalanya akan dilakukan tindakan fiksasi ektremitas apabila dinilai dapat mengancam lingkungan dan diri sendiri. Prosedur pembatasan gerak dengan melakukan fiksasi oleh perawat terlatih dilakukan dengan tujuan dapat meredam gejala perilaku kekerasan yang dialami klien.

\section{METODE PENELITIAN}

Penelitian ini merupakan penelitian kuantitatif dengan menggunakan desain Pre Eksperiment pretest-post test dan desain penelitian yang digunakan adalah one group pre dan post test design dimana pengukuran dilakukan sebanyak 2 kali, sebelum penerapan $S$ (01) disebut pre test dan setelah diberikan pendidikan kesehatan (02) disebut post test. Tujuan dari penelitian ini adalah untuk melihat pengaruh penerapan strategi pelaksanaan perilaku kekerasan terhadap klien skizofrenia di Rumah Sakit Jiwa Daerah Provinsi Jambi. Populasi dalam penelitian ini adalah seluruh klien skizofrenia yang mengalami resiko perilaku kekerasan yaitu sebanyak 80 orang dengan sampel penelitian ada sebanyak 30 responden.

\section{HASIL DAN PEMBAHASAN Karakteristik Responden}

Berdasarkan penelitian, diketahui bahwa gambaran karakteristik responden berdasarkan umur menunjukan sebagian besar merupakan tingkat umur dewasa awal 26 - 35 tahun sebanyak 14 responden $(46,7 \%)$. Jenis kelamin diperoleh gambaran menunjukan sebagian besar adalah laki-laki 
sebanyak 23 responden (76,7\%). sebagian besar responden status Pendidikan terakhir diperoleh gambaran perkawinannya menikah sebanyak 14 sebagian besar adalah berpendidikan responden $(46,7 \%)$. menengah sebanyak 21 responden $(70,0 \%)$. Status perkawinan diperoleh gambaran

Tabel 2 Skor tanda gejala skizofrenia sebelum dilakukan penerapan strategi pelaksanaan perilaku kekerasan

\begin{tabular}{lllllll}
\hline No & \multicolumn{1}{c}{ Variabel } & Mean & Min & Max & SD & N \\
\hline 1 & $\begin{array}{l}\text { Tanda gejala skizofrenia } \\
\text { (pre-test) }\end{array}$ & 17,00 & 13 & 24 & 2,779 & 30 \\
\hline
\end{tabular}

Berdasarkan tabel 2 dapat dilihat bahwa gambaran tanda gejala skizofrenia sebelum diberikan penerapan strategi pelaksanaan perilaku kekerasan didapatkan nilai rata-rata (mean) yaitu 17,00 , dengan nilai minimun 13 dan nilai maksimum 24 , serta standar deviasi (SD) 2,779.

Hawari menyatakan bahwa tanda gejala positif dari penderita skizofrenia yang biasanya ditemukan antara lain gaduh gelisah, mondar-mandir, agresif, merasa dirinya adalah orang besar dan meremehkan orang lain. ${ }^{7}$ Sedangkan untuk tanda gejala yang paling sedikit ditemukan adalah item pernyataan nomor 17 yaitu mengatakan merupakan orang yang berkuasa

Tabel 3 Skor tanda gejala skizofrenia sebelum dilakukan penerapan strategi pelaksanaan perilaku kekerasan

\begin{tabular}{lllllll}
\hline No & \multicolumn{1}{c}{ Variabel } & Mean & Min & Max & SD & N \\
\hline 1 & $\begin{array}{l}\text { Tanda gejala } \\
\text { skizofrenia (post-test) }\end{array}$ & 7,93 & 4 & 14 & 2,348 & 30 \\
\hline
\end{tabular}

Berdasarkan tabel 3 dapat dilihat bahwa gambaran tanda gejala skizofrenia setelah diberikan penerapan strategi pelaksanaan perilaku kekerasan didapatkan nilai ratarata (mean) yaitu 7,93 dengan nilai minimun 4 dan nilai maksimum 14, serta standar deviasi (SD) 2,348.

Penurunan tanda gejala skizofrenia yang signifikan merupakan respon positif yang diharapkan dari tindakan keperawatan yang diberikan oleh perawat. Semakin banyak terjadinya penurunan artinya semakin terasa pengaruh pemberian intevensi.Dalam hal pemberian strategi pelaksanaan perilaku kekerasan gejala yang paling signifikan mengalami penurunan adalah ungkapan pasien ingin memukul orang lain. Setelah periode akut serangan amuk teratasi, penderita dengan perlahan mampu berpikir secara rasional, intervensi yang diberikan membantu untuk dapat berpikir secara lebih rasional. Sehingga pasien bisa mengendalikan emosi dan marah yang dialami.

Penurunan hasil penilaian tanda gejala perilaku kekerasan sebelum dan setelah intervensi mencerminkan tingkat keefektifan atau pengaruh dari intervensi 
yang diberikan. Semakin tinggi terjadinya penurunan (signifikan), bearti semakin besar pengaruh dari intervensi yang diberikan. Namun demikian, efektif dan tidaknya intervensi yang diberikan dapat yang berlainan. dipengaruhi juga oleh faktor lainnya juga, sehingga intervensi yang sama terhadap 2 subjek yang berbeda dapat menghasilkan hasil

\section{Tabel 4 Pengaruh Penerapan Strategi Pelaksanaan Perilaku Kekerasan terhadap Tanda Gejala SKizofrenia}

\begin{tabular}{|c|c|c|c|c|c|}
\hline Variabel & Mean & SD & SE & P-Value & $\mathrm{N}$ \\
\hline $\begin{array}{l}\text { Sebelum penerapan } \\
\text { strategi pelaksanaan }\end{array}$ & 17.00 & 2.779 & .507 & \multirow[b]{2}{*}{0,000} & \multirow[b]{2}{*}{30} \\
\hline $\begin{array}{l}\text { Setelah penerapan } \\
\text { strategi pelaksanaan }\end{array}$ & 7.93 & 2.214 & .404 & & \\
\hline
\end{tabular}

Hasil penelitian yang diperoleh dari 30 responden tentang penerapan strategi pelaksanaan perilaku kekerasan terhadap tanda gejala skizofrenia di ruang rawat inap RSJD Provinsi Jambi Tahun 2020, diketahui nilai rata-rata tanda gejala skizofrenia sebelum dilakukan penerapan strategi pelaksanaan perilaku kekerasan (pre test kelompok sebelum) adalah 17.00 dengan standar deviasi 2.779 , sedangkan nilai rata-rata tanda gejala skizofrenia setelah penerapan strategi pelaksanaan perilaku kekerasan (post test kelompok setelah) adalah 7.93 dengan standar deviasi 2.214, dari hasil tersebut penurunan tanda gejala skizofrenia yang terjadi sebelum dan sesudah penerapan strategi pelaksanaan perilaku kekerasan adalah sekitar .507 untuk sebelum penerapan strategi pelaksanaan dan .404 setelah penerapan strategi pelaksanaan dan hasil statistik 22.064. Berdasarkan hasil uji statistik didapatkan nilai $p$-value $=0.000(\mathrm{p}<0,05)$ dari hasil penelitian tersebut menunjukkan bahwa ada pengaruh penerapan Strategi Pelaksanaan Perilaku Kekerasan terhadap Tanda Gejala Skizofrenia di Ruang Rawat Inap RSJD Provinsi Jambi Tahun 2020.
Skizofrenia adalah gangguan psikotik yang bersifat kronis atau kambuh yang ditandai dengan terdapatnya perpecahan (schism) antara pikiran, emosi dan perilaku pasien yang terkena. Perpecahan pada pasien digambarkan dengan adanya gejala fundamental (atau primer) spesifik, yaitu gangguan pikiran yang ditandai dengan gangguan asosiasi, khususnya kelonggaran asosiasi. Gejala fundamental lainnya adalah gangguan afektif, autism, dan ambivalensi. Sedangkan gejala sekundernya adalah waham dan halusinasi. ${ }^{11}$

Skizofrenia juga merupakan penyakit otak yang timbul akibat ketidakseimbangan pada dopamin, yaitu salah satu sel kim didalam otak. Dia adalah gangguan jiwa psikotik paling lazim dengan ciri hilangnya perasaan afektif atau respon emosional dan menarik diri dari hubungan antar pribadi normal. Seringkali diikuti delusi (keyakinan yang salah) dan halusinasi (persepsi tanpa ada rangsangan panca indra). Penyakit ini ditakuti sebagai gangguan jiwa yang berbahaya dan tidak dapat dikontrol, dan mereka yang terdiagnosis penyakit ini digambarkan 
sebagai individu yang tidak mengalami masalah emosional atau psikologis yang terkendali dan memperhatikan prilaku yang aneh dan amarah (Videbac, 2008).

Skizofrenia berdampak buruk jika gejala dan tanda dari skizoprenia diabaikan, akibat yang ditimbulkan pun akan berbahaya, baik bagi penderita itu sendiri maupun orang yang disekitarnya (Stuart,2013). Perilaku agresif pada penderita skizofrenia merupakan tanda gejala yang mengarah kepada perilaku yang maladaptive, seperti : mengancam mau menyakiti seseorang, bermusuhan dan menarik diri (Keliat, 2013). Hal ini membutuhkan penanganan yang tepat dan professional.

Menurut Maramis, bahwa penatalaksanaan yang dapat dilakukan kepada pasien skizofrenia terbagi menjadi farmakoterapi, terapi electroconvulsive dan psikoterapi. Psikoterapi merupakan penatalaksanaa terhadap masalah emosional seorang pasien yang dilakukan oleh seorang yang terlatih dalam hubungan profesional dengan maksud hendak menghilangkan, mengubah atau menghambat gejala-gejala yang ada, mengoreksi prilaku yang terganggu dan mengembangkan pertumbuhan kepribadian secara positif (Stuar, 2013).

Perilaku yang terganggu pada penderita skizofrenia salah satunya bisa berupa kecendrungan untuk melakukan kekerasan. Perilaku kekerasan merupakan suatu bentuk perilaku yang bertujuan untuk melukai seseorang secara fisik maupun psikologis (Direja, 2011). Psikoterapi yang dapat diberikan oleh tenaga perawat salah satunya ialah pemberian strategi pelaksanaan pada pasien perilaku kekerasan yang terbagi menjadi 4 bagian strategi pelaksanaan yang disebut juga sebagai tindakan keperawatan generalis.

Tindakan keperawatan generalis pada klien perilaku kekerasan dilakukan dalam 4 macam strategi pelaksanaan (SP) yaitu: mengontrol perilaku kekerasan dengan cara fisik yaitu tarik nafas dalam dan pukul kasur bantal, mengontrol perilaku kekerasan dengan cara minum obat secara teratur, mengontrol perilaku kekerasan dengan cara verbal yaitu: menceritakan perilaku kekerasan, bicara baik (meminta, menolak dan mengungkapkan perasaan), mengontrol perilaku kekerasan dengan cara spritual, pada setiap pertemuan klien memasukkan kegiatan yang telah dilatih untuk mengatasi masalah kedalam jadwal kegaiatan harian (Keliat, 2019).

Hasil penelitian ini sejalan dengan hasil penelitian yang dilakukan Suwahyu (2016) yang menyatakan bahwa terdapat penurunan tanda gejala dan peningkatan kemampuan mengontrol perilaku kekerasan sebelum dan sesudah penerapan strategi pelaksanaan dengan nilai $p$ value 0,000 . Penelitian ini sejalan juga dengan penelitian yang dilakukan Saswati (2016) yang menyatakan bahwa ada pengaruh penerapan standar asuhan keperawatan perilaku kekerasan dengan nilai $p$ value 0,000 . Penelitian Putri (2018) menyimpulkan bahwa ada pengaruh signifikant komunikasi terapeutik dalam mengatasi masalah perilaku kekerasan pada pasien skizofrenia dengan nilai $p$ value 0,013

Penelitian yang dilakukan ini memberikan gambaran bahwa tindakan mandiri yang dilakukan perawat dalam membantu mengatasi permasalahan yang diderita pasien khususnya terhadap pasien skizofrenia dengan perilaku kekerasan sangat penting dan sudah seharusnya untuk senantiasa ditingkatkan. Penerapan strategi pelaksanaan perilaku kekerasan yang dilakukan dengan menjalin hubungan interpersonal yang harmonis antara perawat dengan pasien. Peran perawat dalam pelaksanaan tindakan mandiri keperawatan di ruang rawat inap RSJD Provinsi Jambi kedepannya harus lebih ditingkatkan.

Penerapan strategi pelaksanaan yang dilakukan perawat membutuhkan kemampuan komunikasi yang baik, 
sehingga dengan kemampuan komunikasi perawat yang baik dapat mencapai tujuan yang diharapkan yaitu perubahan perilaku pasien menjadi lebih baik dan konstruktif. Beberapa kendala dalam penerapan strategi pelaksanaan di ruang rawat inap RSJD Provinsi Jambi seperti kurangnya tenaga perawat yang handal dan rendahnya motivasi perawat untuk dapat melakukan strategi pelaksanaan secara berkelanjutan harus menjadi catatan serius bagi stakeholder yang terkait.

Menurut peneliti, dengan kesimpulan hasil penelitian ini diharapkan agar penerapan strategi pelaksanaan dapat terus dilakukan dan ditingkatkan secara berkesinambungan oleh perawat di RSJD Provinsi Jambi. Adapun mengenai kendala yang peneliti temukan dalam penelitian ini, diharapkan sebaiknya pihak manajemen RS khususnya bidang keperawatan dapat membuat kebijakan tentang standar operasional prosedur pelaksanaan komunikasi dan pemberian strategi pelaksanaan bagi setiap diagnose keperawatan. Selain itu juga untuk lebih ditingkatkan kembali pelatihan yang terkait dengan mutu asuhan keperawatan, seperti pelatihan manajemen bangsal rawat inap dan pelatihan asuhan keperawatan jiwa terbaru. Selain itu, untuk meningkatkan pengaruh maupun hasil dari Strategi Pelaksanaan (SP) yang masih belum terlalu signifikan pihak manajemen maupun stakeholder terkait dapat memaksimalkan penerapan komunikasi dengan menetapkan SP terhadap diagnosa keperawatan dilakukan setiap shift kerja perawat.

\section{SIMPULAN}

Berdasarkan hasil penelitian didapatkan beberapa kesimpulan : Gambaran tanda gejala skizofrenia dari 30 responden sebelum dilakukan penerapan strategi pelaksanaan perilaku kekerasan di ruang rawat inap RSJD Provinsi Jambi yaitu dengan nilai rata-rata sebesar 17,0 dengan skor tertinggi 24 dari total skor 28 tanda gejala dan skor terendah 13 dari total skor 28. Gambaran tanda gejala skizofrenia dari 30 responden sesudah dilakukan penerapan strategi pelaksanaan perilaku kekerasan di ruang rawat inap RSJD Provinsi Jambi yaitu dengan nilai rata-rata sebesar 7,93 dengan skor tertinggi 13 dari total skor 28 tanda gejala dan skor terendah 4 dari total skor 28. Terdapat pengaruh penerapan strategi pelaksanaan perilaku kekerasan terhadap tanda gejala skizofrenia di ruang rawat inap RSJD Provinsi Jambi tahun 2020 dengan nilai $p$ value $0,000(<0,05)$.

\section{SARAN}

Diharapkan pihak rumah sakit khususnya bidang keperawatan dapat terus berupaya meningkatkan pelayanan kesehatan dan penanganan masalah kesehatan dengan pelaksanaan tugas mandiri perawat khususnya dalam menerapkan SP, seperti melakukan kebijakan tentang evaluasi terhadap kinerja perawat dalam memberikan SP pada pasien setiap shift jaga. Selain itu, untuk standar strategi pelaksanaan diagnosa keperawatan jiwa, diharapkan dapat lebih diupgrade dengan standar asuhan keperawatan jiwa terbaru. Bagi peneliti selanjutnya dapat melakukan peneliti lanjutan tentang penerapan strategi pelaksanaan keperawatan lainnya khususnya untuk standar asuhan keperawatan jiwa terbaru.

\section{DAFTAR PUSTAKA}

Kaplan \& Sadock. 2007. Buku Ajar Psikiatris Klinis (edisi 2) Jakarta : EGC

Kunter. 2009. Skizofrenia. Dalam jurnal kesehatan. http//subscrif.com. diakses tanggal 10 Februari 2018.

WHO. 2016. Skizofrenia. Di akses melalui http//jurnal.kesehatan.jiwa.com

Kemenkes RI.(2018). Riset Kesehatan Dasar (Riskesdas) 2018. Jakarta: Badan Penelitian dan Pengembangan Kesehatan 
Yosef. 2010. Keperawatan Jiwa. Bandung : Refika Aditama

Videbeck, S. 2008. Buku Ajar Keperawatan Jiwa. Jakarta : EGC

Hawari, Dadang. 2012. Skizofrenia edisi ke3 Pendekatan Holistik (BPSS), BioPsiko-Sosial-Spritual.Badan Penerbit Fakultas Kedokteran Universitas Indonesia

Direja Ade H.S. 2011. Buku Asuhan Keperawatan Jiwa. Jakarta : Medikal Book

Keliat, Budi. 2019. Asuhan Keperawatan Jiwa. Jakarta : EGC

Keliat, Budi. dkk. 2013. Model Praktek Keperawatan Profesional. Jakarta : FKUI

Stuart, G.W. 2013. Buku Saku Keperawatan Jiwa, Edisi 5. Jakarta: EGC

Maramis, W.F. 2008. Catatan Ilmu Kedokteran Jiwa. Surabaya : Airlangga University Press
Keliat, Budi Anna. 2011. Keperawatan Kesehatan Jiwa Komunitas. Jakarta : EGC

Suwahyu Romy. 2016. Gambaran Tanda Gejala dan Kemampuan Pasien Mengontrol Perilaku Kekerasan Sebelum dan Setelah Penerapan Strategi Pelaksanaan (SP) di Rumah Sakit Jiwa Daerah Provinsi jambi. Skripsi. Universitas Jambi

Saswati N. 2016. Pengaruh Penerapan Standar Asuhan Keperawatan Perilaku Kekerasan. Jurnal Keperawatan.

Putri, V.S, dkk. 2018. Pengaruh Strategi Pelaksanaan Komunikasi Teraupetik terhadap Resiko Perilaku Kekerasan pada Pasien Gangguan Jiwa di RSJD Provinsi Jambi. Jurnal Akademika STIKBA Jambi Volume 7 